\title{
THE INDONESIAN CONSTITUTIONAL COURT AND THE DEMOCRATIC INSTITUTIONS IN JUDICIAL REVIEW
}

\author{
Andy Omara \\ Ph.D. Candidate University of Washington School of Law, Seattle, Washington, USA \\ Faculty of Law, Universitas Gadjah Mada, Yogyakarta, Indonesia \\ andy.omara@mail.ugm.ac.id
}

\begin{abstract}
This paper focuses on the relationship between the Indonesian Constitutional Court, the legislature, and the executive in judicial review. It aims to explain the Court strategies in deciding judicial review cases related to the right to work in relation with the executive and the legislature. It appears that while constitutionally the Court is granted with a strong form of judicial review (as reflected in the finality of its decisions), it also employed other approaches in deciding cases related to the right to work. These approaches include the declaration of incompatibility, conditional decision, and the invalidation of a statute in its entirety. This paper argues that Katharine G. Young's typology of judicial review is quite helpful as an interpretive tool to understand the Court approaches when it decided cases related the right to work. The use of various approaches by the Court affected the relationship between the Court, the executive, and the legislature. This is because the executive and the legislature are the implementing agencies of the Court rulings.
\end{abstract}

Keywords: Constitutional Court, Democratic Institutions, Judicial Review

\section{INTRODUCTION}

\subsection{Background}

The introduction of the Indonesian Constitutional Court in the most recent constitutional amendments in 1999-2002 showed Indonesia's strong commitment on human rights protection, constitutionalism, and democracy. The Court's power to conduct judicial review and to settle dispute on general elections ${ }^{1}$ 
provides a legal avenue for the people to defend their constitutional rights. This paper will analyze the relationship of the Constitutional Court and the democratic institutions (i.e. the government and the parliament) in judicial review. Generally, it is the duty of the legislature to make laws, the duty of executive to carries of laws, and the duty of the judiciary to enforce the laws. In judicial review however, these three institutions have unique relationship. The constitutional court does not enforce the made by the legislature, it instead reviews the constitutionality of laws against the constitution. The government and the parliament are the lawmakers while the constitutional court determines the constitutionality of statutes -the product of the lawmakers. In judicial review, the constitutional court plays a significant role in rendering decisions on judicial review. However, this important role ends when it comes to the implementation. The constitutional court heavily depends on the government and the legislature in effectuating its rulings.

\subsection{Question}

This article aims to answer an important question: what were the Constitutional Court approaches, as mentioned in its rulings, regarding the enforcement of its decisions? It argues while the Constitution has determined the court's approach in rendering decisions, in practice the Court employed different strategies other than the one that is expressly stated in the 1945 Constitution (post 1999-2002 constitutional amendments).

The constitutional court is often called as a counter majoritarian institution. ${ }^{2}$ This is because the powers of this new Court to a certain extent contradict with the will of the democratic institutions. On the one hand, the government and the parliament have the power to enact statutes; on the other hand, the Court has the power to invalidate statutes-- the product of two state institutions, who are elected by the people through general elections. Alexander Bickel, The Least Dangerous Branch: The Supreme Court at the Bar of Politic (London: Yale University
Press, 1986), 16. 
Conceptually, the duty of the legislative is to make laws, the government's duty is to carry out the laws, and the duty of the court is to enforce the laws. In judicial review, however, the Court is the primary actor. It has the final say to decide whether a statute is in line with the Constitution. This important role, however, ends when it comes to the implementation of its rulings. The Court relies on the government and the legislature in effectuating its rulings. The Court does not have the sword and the purse ${ }^{3}$ to effectuate its decisions.

Using four judicial review cases of the right to work, this paper will examine how these three institutions interact in this legal review. Cases related to the right to work are selected because these cases show the unique relation between the court, the government, and the parliament. This article will use Katharine G. Young typology of judicial review to answer the research question mentioned above. Young's typology suggests in judicial review, the court decisions will likely reflect one of the five stances. These five stances include deferential, conversational, experimental, managerial, or superior/peremptory. ${ }^{4}$ This paper will also use Tracey E. George and Lee Epstein "legal and extralegal" model ${ }^{5}$ to understand the factors that were taken into account when the Court decides cases.

This paper proceeds as follows: Part I begin with an explanation of legal and extralegal model (i.e.,legal formalism and legal realism) and Young's five stance of judicial review. Part II applies the theories mentioned above to the constitutional court rulings on judicial review of cases related to the right to work. To begin with, this part selects the Constitutional Court decisions i.e. court rulings on the right to work. Then it summarizes these selected cases to understand the context of each case. These court rulings are then analyzed to answer the research question mention above. After all

\footnotetext{
${ }^{3}$ Alexander Hamilton, "The Federalist Papers : No. 78" (The Judiciary Department From McLEAN'S Edition), accessed October 31, 2017, http://avalon.law.yale.edu/18th_century/fed78.asp.

4 Katharine Young, Constituting Economic and Social Rights (Oxford University Press: Oxford University Press, 2012), 174. See also Katharine Young, "A Typology of Economic and Social Rights Adjudication: Exploring the Catalytic Function of Judicial Review," International Journal of Constitutional Law 8, no. 3 (2010): 385.

5 Lee Epstein and Tracey George, "On the Nature of Supreme Court Decision Making," The American Political Science Review 86, no. 2 (1992): 323.
} 
cases are analyzed, it then reviews all court decisions to find out whether there is a pattern or a tendency when the Court decided judicial review cases on right to work. This paper ends with a conclusion.

\section{DISCUSSION}

\subsection{How a Court Reach a Decision: Between Legal Formalism and Legal Realism}

Do factors outside the legal rules influence judges' consideration when they decide cases? Or do judges decide cases based on what the law says? If judges have a similar view about the legal rules and they do not have significant difference among them in a way they understand the law to decide a similar issue, it is likely that the court will come up with the same legal arguments in its rulings. In practice, it is not uncommon that judges provide different opinions when they decide cases. It is likely that factors outside the legal rules influence judicial decisions.

Theoretically, there are two approaches on how a court reaches a decision: legal formalism and legal realism. ${ }^{6}$ Legal formalism posits that a court renders its decisions based on legal rules.7 The court should apply the legal principles which existed before all court decisions. It is the nature of law to require a mechanical application of its rules and principles. Judges' duty is to find the law, not to make the law. They should remain faithful to the norms derived from the constitution. The important elements of legal factors include the intent of the framers, the use of neutral principles, and precedent. ${ }^{8}$

Legal realism states that the court considers outside legal rules such as sociological, psychological and political factors in deciding cases. ${ }^{9}$ It is important for judges to make a choice as the legal rules to be applied. This theory believes

\footnotetext{
${ }^{6}$ Brian Leiter, "Legal Formalism and Legal Realism: What Is the Issue?," University of Chicago Public Law \& Legal Theory Working Paper 320 (2010): 111, http://chicagounbound.uchicago.edu/cgi/viewcontent. cgi?article $=1178 \&$ context=public_law_and_legal_theory.

${ }^{8}$ Richard Pacelle Jr, Brett Curry, and Marshall, Decision Making by the Modern Supreme Court (Cambridge: Cambridge University Press, 2011), 29.

9 Leiter, "Legal Formalism and Legal Realism: What Is the Issue?," 111.
} 
that existing laws are never complete. As a result, they cannot be directly applied to very specific cases in the real world.

\subsection{Katharine G. Young's Typology of Judicial Review}

One of the common debates regarding judicial review is that whether a court is the appropriate institution to deal with practical problems that often requires the government involvement to resolve these problems. For instance, in settling problems which requires significant financial resources is the Court the most appropriate institution? Or is the government more suitable to decide. If a court handles such cases, there is a criticism that a court does not represent the will of the people (lack of democratic legitimacy). It also does not have the practical knowledge in dealing with such issues. On the other hand, the government does not always appropriately use its powers based on the Constitution. The government as political body often uses its powers to advance its political agenda which may not in line with the constitution. Both positions potentially create judicial supremacy or government supremacy.

To resolve the above-mentioned problems, Katharine G. Young introduces a typology of judicial review. ${ }^{10}$ Using the South African Constitutional Court experience as an example, Young defines five stances of judicial review: deferential, conversational, experimental, managerial and peremptory." By deferential, she means that the court assumes that the decision-making authority is greater placed on the legislature. By conversational, she means the court relies on the ability to have inter-branch dialogue to resolve the determination of rights. Experimental stance assumes that the court seeks to involve the relevant stakeholders including the government in resolving the economic and social rights problems. Managerial stance means that the court assumes direct responsibility in interpreting substantive and supervising their protection with strict and detailed plans. And peremptory stance assumes that the court is superior in interpreting the rights and in commanding and controlling and immediate response. She labels these

\footnotetext{
${ }^{10}$ Young, "A Typology of Economic and Social Rights Adjudication: Exploring the Catalytic Function of Judicial Review," 385

${ }^{11}$ Ibid.
} 
five stances "the catalytic function of judicial review" because they may enhance the relationship between the court and the legislature to achieve a right protective outcome. ${ }^{12}$ This theory provides a new approach on how the economic and social rights should be adjudicated. This approach, in which to a certain extent require inter-branches dialogue, may address the problems of legislative supremacy and judicial supremacy. This paper will use Young's theory as a reference to answer the research question because it provides the most comprehensive typology on how the role and the relation of the court and the legislative/the executive in judicial review cases.

\subsection{Applying Theories to Practice: The Constitutional Court Approaches in Judicial Review of Laws Related Right to Work}

This part will analyze four court decisions: Outsourcing case,13 Minimum Educational Background to work Case,${ }^{14}$ Fair treatment in employment case, ${ }^{15}$ and the right of the workers' wages case. ${ }^{16}$ The analysis will cover the approaches in deciding these cases and the factors that were taken into account by the Court when it decides these four judicial review cases.

\subsubsection{Outsourcing Case ${ }^{17}$}

In this case, 37 individuals of activists and NGOs on labor right challenged the constitutionality of Law 13/2003 on Manpower to the Court arguing that some provisions of this law limited right to association, right to strike, and right to work (outsourcing policy). This was because this law required a minimum threshold to form a worker union. It also required the employees to inform the management 7 days before they exercise their right to strike. The outsourcing policy stated in this law, the petitioners argued, did not respect the workers

\footnotetext{
12 Ibid.

${ }_{13}$ Judicial Review Number 13 of 2003 on Manpower, No. 012/PUU-1/2003 (The Constitutional Court of the Republic of Indonesia 2003).

14 Judicial Review Number 39 of 2004 on Placement and Protection of the Indonesian Migrant Workers, No. 019-020/ PUU-III/2005 (The Constitutional Court of the Republic of Indonesia 2005).

15 Judicial Review Number 13 of 2003 on Manpower, The Constitutional Court of the Republic of Indonesia 2003. Decision Number 58/PUU-IX/2011.

${ }^{16}$ Judicial Review Number 13 of 2003 on Manpower against the 1945 Constitution, No. 67/PUU-XI/2013 (The Constitutional Court of the Republic of Indonesia 2003).

17 Judicial Review Number 13 of 2003 on Manpower, The Constitutional Court of the Republic of Indonesia 2003. Decision Number 12/PUU-1/2003.
} 
right to have job security as this law allowed to company to dismiss the workers once the projects completed.

In a split decision, the Court ruled that the minimum threshold to form an association and the requirement to inform the management 7 days before the employee's strike was unconstitutional, but the provisions on outsourcing were constitutional. ${ }^{18}$ In this regard, the Court stated that outsourcing in this law did not reflect a modern form of slavery. Articles $64-66$ of this law sufficiently guaranteed the right of workers. Two Justices ${ }^{19}$ dissented. They were of the opinion that this law did not sufficiently guarantee the right of workers, as reflected in provisions concerning: outsourcing, limiting right to form a union, and limiting the right to strike. These articles, the dissenters stated, lead to the uncertainty of the workers' future. It also degraded workers dignity.

In this case, the majority applied legal factors. They referred to relevant provisions of the constitution to determine the constitutionality of the provisions of the law. Similarly, the dissenters also adopted the same rules. But they ended up with a very different conclusion. The dissenters believed that outsourcing did not protect the right of the workers. It created uncertainty to the workers' future.

The court ruling, in this case, reflects a strong form of judicial review in the sense that the Court declared the provisions of the law were inconsistent with the Constitution and invalidated these provisions. ${ }^{20}$ In Young's typology, this court decision largely reflects a peremptory stance. A peremptory stance is closer to judicial review that either strikes down or upholds the legislation. ${ }^{21}$ It involves a thorough examination of the government legislation. If the Court finds a constitutional infringement, it overturns the legislation. Similarly, in this case, the Court rigorously scrutinized the content of Manpower Law, particularly regarding whether the Law was consistent with the Constitution. It found a

\footnotetext{
${ }_{18}$ Ibid., 115 .

19 The Constitutional Court of the Republic of Indonesia, "Sang Penggembala: Perjalanan Hidup Dan Pemikiran Hukum A. Mukthie Fadjar (Hakim Konstitusi Periode 2003-2008)," (Sekretariat Jenderal dan Kepaniteraan MKRI, 2008), 55-63.

${ }^{20}$ Mark Tushnet, "New Forms of Judicial Review and the Persistence of Rights-and Democracy-Based Worries," Wake Forest Law Review 38 (2003): 817.

${ }^{21}$ Young, "A Typology of Economic and Social Rights Adjudication: Exploring the Catalytic Function of Judicial Review," 385.
} 
constitutional infringement, and invalidated the statute. ${ }^{22}$ This Court decision, however, did not give any interpretation of the law or give guidance for the lawmakers to keep the law constitutional.

\subsubsection{Minimum Educational Background to Work Case ${ }^{23}$}

The petitioners, three companies focusing migrant workers, challenged the constitutionality of article $35 \mathrm{~d}$ of the Law 39/2004 ${ }^{24}$ which requires a person graduated from middle school to be eligible to work as a migrant worker who would work for individuals - not for companies. They argued that this Article violated the right to work as guaranteed by Article 27 (2) of the Constitution. The Government argued that setting the minimum educational background for migrant workers aims to protect the interest of migrant workers such as preventing children exploitation and improving the quality of migrant workers' educational background. ${ }^{25}$ Concerning the minimum age to work as migrant workers, the government argued that working overseas needs skills, physical and emotional readiness maturity that may be achieved if they reach 21 years old. ${ }^{26}$ The Court agreed with the government's' argument regarding the minimum age requirement to be migrant workers. This limitation was important to protect the migrant worker's interests. ${ }^{27}$ The Court, however, did not agree on the minimum educational background requirement. In a split decision, it declared that setting the minimum educational background to be a migrant worker beyond the requirement determined by specific jobs did not have a solid basis. The Court ruled that Article $35 \mathrm{~d}$ was inconsistent with the Constitution. As a result, it did not legally binding.

\footnotetext{
22 Judicial Review Number 13 of 2003 on Manpower against the 1945 Constitution, No. 001/PUU-1/2003 (The Constitutional Court of the Republic of Indonesia 2003). Judicial Review Number 13 of 2003 on Manpower against the 1945 Constitution, No. 021/PUU-1/2003 (The Constitutional Court of the Republic of Indonesia 2003). Judicial Review Number 13 of 2003 on Manpower against the 1945 Constitution, No. 022/PUU-1/2003 (The Constitutional Court of the Republic of Indonesia 2003).

${ }^{23}$ Judicial Review Number 39 of 2004 on Placement and Protection of the Indonesian Migrant Workers. Decision No. 019-020/PUU-III/2005. See also The Constitutional Court of the Republic of Indonesia, "Catatan Hakim Konstitusi Soedarsono: Putusan Mahkamah Konstitusi Tanpa Mufakat Bulat" (Sekretariat Jenderal dan Kepaniteraan MKRI, 2008), 299.

24 "Indonesian Law Number 39 of 2004 on the Placement and Protection of the Indonesian Migrant Workers" (2004).

${ }^{25}$ Judicial Review Number 39 of 2004 on Placement and Protection of the Indonesian Migrant Workers at 87. Decision No. 019-020/PUU-III/2005.

${ }^{26}$ Ibid., 59-60.

${ }^{27}$ Ibid., 108.
} 
Two Justices dissented ${ }^{28}$. Justice Natabaya questioned the legal standing of the petitioners. The petitioners did not experience constitutional damage because of Article $35 \mathrm{~d}$. For him, the potential petitioners, in this case, were individuals who could not be migrant workers because they did not graduate from middle school. For this reason, he argued, this petition should be denied.

Justice Achmad Roestandi was of the opinion that setting a minimum education requirement was the lawmakers' domain to decide - not the Court. ${ }^{29}$ The government and the legislature had some alternatives to determine the policy concerning the placement of the Indonesian migrant workers. The lawmakers had chosen that to be eligible as a migrant worker a person should graduate from middle school. This policy could not be seen as a form of discrimination because this requirement applied to everyone. The different treatment between those who were middle school graduates and those who were not reflected justice. It treated two different things differently. Justice Achmad Roestandi believed that the Law, in this case, acts as a tool of social engineering. This provision would motivate those who wanted to be migrant workers to finish their middle school education. $3^{\circ}$

In this case, the Court ruling largely reflected a peremptory stance. Young's peremptory review assumed that the Court would overturn or sustain legislation if it found legislation was consistent or inconsistent with the Constitution. Similarly, in this case, the Court found the Migrant Worker Protection Law was inconsistent with the Constitution. As a result, the Court overturned the provisions of this Law. One of the dissenters, Justice Achmad Roestandi, believed that the issue in this petition belongs to the lawmakers to decide. As a democratically elected body, the lawmaker was the most proper institution to decide matters that related to the interests of the people. Justice Roestandi's approach appeared to be more restrained or deferential. He did not want the court to be involved in matters that belonged to other branches governments i.e. the lawmakers.

\footnotetext{
${ }^{28}$ Justice HAS Natabaya and Justice Achmad Roestandi.

${ }^{29}$ Judicial Review Number 39 of 2004 on Placement and Protection of the Indonesian Migrant Workers at $116-17$. Decision No. 019-020/PUU-III/2005.

$3^{0}$ lbid., 116.
} 
The Court should be committed to its judicial function and is not involved in lawmaking function.

A year later, two petitions ${ }^{31}$ submitted to the Court by nine individuals who could not work overseas as migrant workers because they were under 21 years old. The petitioners challenged the constitutionality of Article 31 (a) of Law 39/2004 on Manpower which set 21 years old as the minimum age to work overseas as migrant workers. ${ }^{32}$ They argued that this Article was inconsistent with Article 27 (2) and $28 \mathrm{D}$ (2) of the Constitution which guarantee a right to work for every citizen and be treated fairly and equally at work.

In its consideration, the Court agreed that right to work was part of economic, social and cultural rights. It was considered as a positive right which needs government active involvement in the realization of this right. The Court referred to its previous decision (Decision 019-020/PUU-III/2005) which stated that the age requirement to work is the proper policy to avoid underage labor. The Court also referred to Article 2 of the ICCPR to explain the term discrimination. The Court found that Article 2 did not explicitly mention age as a factor that could lead to discrimination. ${ }^{33}$ Further, the Court took into consideration the European Council Directive ${ }^{34}$ to explain that different treatment on grounds of age did not constitute discrimination if they are objectively and reasonably justified by a legitimate aim. This includes the fixing of minimum conditions of age. The Court in a 5-4 decision ruled that Article 35 (a) was consistent with the Constitution.

Four justices dissented. They believed that Article 35 (a) of Law on Manpower was discriminatory and was inconsistent with Article 27 and Article 28 of the Constitution. Justice Laica Marzuki criticized the government's argument which concluded that workers aged 21 years old and up would be less possibility to

\footnotetext{
${ }^{31}$ As reflected in Judicial Review Number 39 of 2004 on Placement and Protection of the Indonesian Migrant Workers against the 1945 Constitution, No. 028-029/PUU-IV/2006 (The Constitutional Court of the Republic of Indonesia 2006). Decision No. 028-029/PUU-IV/2006. See also The Constitutional Court of the Republic of Indonesia, "Ikhtisar Putusan Mahkamah Konstitusi 2003-2008" (Sekretariat Jenderal dan Kepaniteraan MKRI, 2008), 671-74. ${ }^{32}$ Especially those who would work for individuals -not for companies.

33 Article 2 ICCPR "Each State Party to the present Covenant undertakes to respect and ensure to all individuals within its territory and subjects to its jurisdiction the rights recognized in the present Covenant, without distinction of any kind such as race, color, sex, language, religion, political or other opinion, national or social origin, property, birth or other status.

34 The European Council Directive 2007/78/EC of 27 November 2000 establishing a general framework for equal treatment in employment and occupation.
} 
be sexually harassed and they were more mature. 35 There was no evidence that confirmed this argument. In addition, national laws i.e. Law on Manpower and Law on Children Protection defines children as individuals under 18 years old. This means 18 years old should be the bottom line to work --not 21 years old.

Justice Abdul Mukthie Fadjar in a relatively similar ground stated that Article 35 a violated the right to work which was guaranteed by the constitution. There was no convincing evidence that workers aged 21 years old would be less likely to be sexually harassed or they were more mature.

Justice Maruarar Siahaan stated that the right to work was closely related to right to life. A person could not live without working. By working, an individual could fulfill his basic needs for life. In setting his argument, he referred to the Indian Supreme Court decision which connects right to work with right to livelihood. ${ }^{36}$ He concluded the age limitation was a violation of right to work which was part of right to life - a nonderogable right which was constitutionally guaranteed. ${ }^{37}$

Justice Harjono stated that the ILO Convention which had been ratified by Indonesian government set 18 years old as the minimum age to work. ${ }^{38}$ The 1945 Constitution guarantees right to work which closely related to right to life (art. 28A). In addition, every person has the right to work and to be treated equally at work (art. 28D (2)). Every individual is also free to choose jobs, residence to live in Indonesian and leave it and has the right to return (art. 28E (1)). Therefore, the minimum age requirement as stated in Article 35 a could disadvantage the constitutional right of individuals who had not reached 21 to work as migrant workers and to choose a residence and to return as guaranteed by the Constitution.

\footnotetext{
35 Judicial Review Number 13 of 2003 on Manpower, No. 028-029/PUU-IV/2006 (the Constitutional Court of the Republic of Indonesia 2006).

${ }^{36}$ Ibid., 69. Decision No. 028-029/PUU-IV/2006. See also Maruarar Siahaan, Undang-Undang Dasar 1945: Konstitusi Yang Hidup (Jakarta: Sekretariat Jenderal dan Kepaniteraan MKRI, 2008), 195-99.

37 Judicial Review Number 13 of 2003 on Manpower, the Constitutional Court of the Republic of Indonesia 2006 at 70-71. Decision No. 028-029/PUU-IV/2006.

${ }^{38} \mathrm{lbid}$., 72. Decision No. 028-029/PUU-IV/2006. See also The Constitutional Court of the Republic of Indonesia, "Konstitusi Sebagai Rumah Bangsa: Pemikiran Hukum Dr. Harjono, S.H., M.C.L. Wakil Ketua MK" (Sekretariat Jenderal dan Kepaniteraan MKRI, 2008), 254.
} 
The majority utilized legal approach by referring to the ICCPR and a European Directive in rendering its decision. It did not refer to specific national legislation because the majority argued that there was no common standard regarding the age among statutes. In addition, it also cited its previous decision in a similar case which also clearly reflected a legal approach.

The dissenters used a similar approach. However, they used this approach quite differently. While the majority used international covenants as their reference, the dissenters consulted with an international covenant (the ILO), national legislation, and the provisions of the Constitution. One Justice cited the Indian Supreme Court decision to support his argument.

The court ruling showed the Court's adoption of peremptory stance. Peremptory review assumes that the court would invalidate or sustain a law once the court found that the law was consistent or inconsistent with the constitution. Likewise, in this case, the Court invalidated provisions which were inconsistent with the Constitution. By rendering this decision, the Court essentially controlled the realization this right. This court ruling did not provide an opportunity for the other branches of government to discuss with the court regarding the realization of these rights. In other words, this ruling did not consider the likelihood of a favorable legislative or executive response.

\subsubsection{Fair Treatment in Employment Case $^{39}$}

This petition was submitted by a worker who did not receive monthly wage on time for more than three months. When she filed this case to the industrial disputes settlement body asking for work dismissal, the company then paid her on time. As a result, the petition could not be followed up. This situation, she believed, violated her right to get fair and proper treatment in employment.

She then filed a petition to the Constitutional Court challenging the constitutionality of Article 169 (1) c of Law 13/2003 on Manpower which stated that worker(s) could file a work dismissal to industrial dispute settlement body

39 Judicial Review Number 13 of 2003 on Manpower, No. 58/PUU-IX/2011 (the Constitutional Court of the Republic of Indonesia 2011). 
if the employer did not pay the workers on time for three consecutive months or more. This provision, she argued, was inconsistent with Article 28D (1) (2) which stipulated that every individual has the right of recognition, guarantees, protection and legal certainty, and equal treatment before the law. Every person has the right to work and to receive fair and proper recompense and treatment in employment.

In its 26 pages decision, the Court was of the opinion that Article 169 (1) c created legal uncertainty and violate workers' constitutional right to receive a just and decent recompense in employment as mentioned in Article 28 (2) the 1945 Constitution. The Court unanimously declared that this provision was inconsistent with the Constitutions if it was not read as follow workers/labors could ask for a work dismissal to the industrial disputes settlement body if the employer did not pay their salary on time for three consecutive months or more, even though the employer then pay their salary on time after that.

In this case, the Court used the petitioner's experience as the basis to decide the case. This approach was not commonly used by the Court. In most cases, it reviewed the provision of the law against the constitution, -not a concrete case against the constitution as reflected in this case. The Court seems to apply a concrete judicial review rather than an abstract judicial review which the Court usually did. In rendering the decision, the Court did not automatically invalidate the provision of the law. It placed a condition so that the article remained constitutional..$^{40}$ The provision of the law was constitutional only if it was interpreted in accordance with the court's interpretation. While the court did not automatically invalidate the provision of the law, its interpretation has changed its original meaning of the law.

The Court's declaration of incompatibility largely resembles a conversational stance or an experimental stance. The court decision in this case did not automatically invalidate a statute. It instead provided an opportunity for the

\footnotetext{
$4^{40}$ Regarding conditional decision can be seen at The Constitutional Court of the Republic of Indonesia, "Menegakkan Tiang Konstitusi: Memoir Lima Tahun Kepemimpinan Prof. Dr. Jimly Asshiddiqie, S.H.,Di Mahkamah Konstitusi" (Sekretariat Jenderal dan Kepaniteraan MKRI, 2008), 175.
} 
legislative, the executive, and the government to discuss the implementation of the court decision.

\subsubsection{The Right of the Workers' Wages Case ${ }^{41}$}

A year later, a similar petition was filed by an ex-worker who challenged the constitutionality of Article 96 of Law 13/2003 which stated that the demand of workers' wage payment would be expired after it exceeded two years. ${ }^{42}$ The petitioner was an ex-security officer in a company who was dismissed from his jobs. After three years left his jobs, he asked the company to pay his remaining wage. The Company argued it could not do so because Article 96 of Law on Manpower limit the payment period for two years. ${ }^{43}$ This provision, the petitioner argued, was in contradiction with Article 28D (1) (2) and 28I (2) of the Constitution which guarantee right to work and receive recompense, equality, and nondiscriminatory treatment.

The Court agreed with the petitioner's argument and ruled that Article 96 disadvantaged the worker's constitutional right to receive his remaining pay. The Court was of the opinion that there should not be a time limit to do so even for the sake of legal certainty because it was the right of the worker to receive payment. ${ }^{44}$ The Court ruled that Article 96 was inconsistent with the 1945 Constitution and it was not legally binding.

One justice ${ }^{45}$ dissented. He was of the opinion that time limit was important in legal relation. It created certainty for both parties the when a legal relation would begin and end. Without time limit, there would be no certainty. Instead of granting the petition, Justice Zoelva suggested that the majority grant the petition with certain conditions (conditional decision) such as Article 96 applied to employers who had good faith to fulfill its obligation but it did not apply to the employer who did not have good faith to pay the workers' wage.

\footnotetext{
${ }^{41}$ Judicial Review Number 13 of 2003 on Manpower against the 1945 Constitution, The Constitutional Court of the Republic of Indonesia 2003 at 67.

${ }^{42}$ Judicial Review Number 13 of 2003 on Manpower against the 1945 Constitution of the Republic of Indonesia, No. 100/PUU-X/2012 (the Constitutional Court of the Republic of Indonesia 2011). Decision No. 100/PUU-X/2012.

43 Ibid., 32-33.

44 lbid., 62.

45 Justice Hamdan Zoelva.
} 
The court ruling, in this case, nullified Article 96 of Law on Manpower. The Court had the final say in determining the constitutionality of the provision of the law. In Young's typology, the court's ruling resembled a peremptory stance. A peremptory stance assumes that the court controls the realization of economic and social rights. The court decision invites either invalidate the law or uphold the law. This decision did not allow the court and the lawmakers to discuss the realization of economic and social right.

In 2013, nine individuals who worked in Pertamina (State-owned Oil Company) filed a petition to the court arguing that Article 95 (4) of Law 13/2003 on Manpower was inconsistent with Article 28D (1) and (2) of the Constitution. ${ }^{46}$ Article 95 (4) stated that in the event of a company went bankrupt or liquidated in accordance with the existing legislation, the payment of workers' wages and their other rights should be paid in priority. The petitioners argued the phrase "should be paid in priority" violated their rights to work and get a reward and equal treatment in industrial relation as guaranteed by the Constitution. They argued that this article was unclear and discriminatory. In practice, worker's wage was paid after the company paid the state rights and its creditors. The petitioners argued this leads to the unclear meaning of Article 95 (4).

In deciding this case, the Court acknowledged its previous decision 18/ PUU-VI/2008 which confirmed that the worker's wage would be paid after the company paid its creditors. In this case, the court took a different position from its previous ruling. The Court framed that the workers' right of payment closely related to right to life which cannot be put aside in any circumstances. Therefore, the government should protect and fulfill this right. The Court differentiated the right of workers and the right of workers to get payment. The right of the workers to get payment should become the top priority. However, it does not apply to the other rights of the workers. The Court partially granted the petition. It declared that Article 95 (4) of Law 13/2003 was inconsistent with the Constitution if it was not interpreted that workers' wage should be paid before

\footnotetext{
${ }_{46}$ Judicial Review Number 13 of 2003 on Manpower against the 1945 Constitution, The Constitutional Court of the Republic of Indonesia 2003. Decision No. 67/PUU-XI/2013.
} 
the company paid the creditors. And the payment of the workers' rights can be made after the company paid the creditors.

In this case, the Court adopted strong form of judicial review by declaring the provision of the law unconstitutional with a specific condition. The Court further gave specific meaning to this provision which was different from the intention of the lawmakers as reflected in the provision of the law. It appeared that the court did not only carry out its judicial function by declaring the provision of the law was unconstitutional, but also changed the meaning of the law which was essentially the function of the legislature. ${ }^{47}$ The court's ruling resembled a peremptory stance. A peremptory stance assumes that the court controls the realization of economic and social rights. The court decision invites either invalidate the law or uphold the law. This decision did not allow the court and the lawmakers to discuss the realization of economic and social right.

\section{CONCLUSION}

This paper has explained the Constitutional Court approaches in deciding judicial review cases related to the right to work. It appears that the Court employs several different approaches other than the one that is constitutionally guaranteed ranging from the Court declaration of null and void, suspension of invalidity, conditional decision, to the invalidation of the law in its entirety. In its early operation, the Court tend to adopt strong form of judicial review. The court seemed move from a strong form judicial review to conditional decisions which can be interpreted as weak form of judicial review if we see that the court maintain the constitutionality of the law. However, it can be seen the adoption of strong form of judicial review if we see the court decision guide the legislature in determining the content of the law.

Katharine G. Young typology of judicial review can be a useful interpretative tool to understand the Court approach in deciding judicial review cases. The Court decision which maintain the validity of statutes even though these statutes

\footnotetext{
${ }^{47}$ Mark Tushnet and Rosalind Dixon, "Weak Form Review and Its Constitutional Relatives: An Asian Perspective in Rosalind Dixon and Tim Ginsburg," in Comparative Constitutional Law in Asia (Massachusetts: Edward Elgar Publishing, 2014), 103.
} 
potentially were not in line with the Constitution showed the court's adoption of conversational stance. The court decisions which provided guidance for the government on how to follow up the court rulings reflected the court adoption of managerial stance. It managed how the government should appropriately follow up the court rulings.

In its early operation, the court tended to adopt peremptory of judicial review and started introducing conversational stance of judicial review. The Court then introduced conditionally constitutional decisions and conditionally unconstitutional decisions. These new approaches had the character of conversational or experimental of judicial review because it maintained the constitutionality of the law even though the court declared the law was not in line with the constitution. It could be also identified as managerial stance of judicial review because it directed the government with its guiding principles on how to follow up the court rulings. Whether the court utilized conversational, experimental, managerial, or peremptory judicial review were not always in line with the types of economic social rights cases the court dealt with.

This paper also has analyzed factors that were taken into account by the Constitutional Court when it decided judicial review cases related to right to work. It appears that the Constitutional Court Justices considered both legal and extra-legal factors when they decided judicial review on right to work cases. There was no consistent pattern when the court used legal factors or extralegal factors.

\section{References}

Bickel, Alexander. The Least Dangerous Branch: The Supreme Court at the Bar of Politic. London: Yale University Press, 1986.

Epstein, Lee, and Tracey George. "On the Nature of Supreme Court Decision Making." The American Political Science Review 86, no. 2 (1992): 323-37.

Hamilton, Alexander. “The Federalist Papers : No. 78." The Judiciary Department From McLEAN'S Edition. Accessed October 31, 2017. http://avalon.law.yale. edu/18th_century/fed78.asp.

Indonesian Law Number 39 of 2004 on the Placement and Protection of the Indonesian Migrant Workers (2004). 
Judicial Review Number 13 of 2003 on Manpower, No. 012/PUU-I/2003 (The Constitutional Court of the Republic of Indonesia 2003).

Judicial Review Number 13 of 2003 on Manpower, No. 028-029/PUU-IV/2006 (the Constitutional Court of the Republic of Indonesia 2006).

Judicial Review Number 13 of 2003 on Manpower, No. 58/PUU-IX/2011 (the Constitutional Court of the Republic of Indonesia 2011).

Judicial Review Number 13 of 2003 on Manpower against the 1945 Constitution, No. 67/PUU-XI/2013 (The Constitutional Court of the Republic of Indonesia 2003).

Judicial Review Number 13 of 2003 on Manpower against the 1945 Constitution, No. 001/PUU-I/2003 (The Constitutional Court of the Republic of Indonesia 2003).

Judicial Review Number 13 of 2003 on Manpower against the 1945 Constitution, No. 021/PUU-I/2003 (The Constitutional Court of the Republic of Indonesia 2003).

Judicial Review Number 13 of 2003 on Manpower against the 1945 Constitution, No. 022/PUU-1/2003 (The Constitutional Court of the Republic of Indonesia 2003).

Judicial Review Number 13 of 2003 on Manpower against the 1945 Constitution of the Republic of Indonesia, No. 100/PUU-X/2012 (the Constitutional Court of the Republic of Indonesia 2011).

Judicial Review Number 39 of 2004 on Placement and Protection of the Indonesian Migrant Workers, No. 019-020/PUU-III/2005 (The Constitutional Court of the Republic of Indonesia 2005).

Judicial Review Number 39 of 2004 on Placement and Protection of the Indonesian Migrant Workers against the 1945 Constitution, No. 028-029/PUU-IV/2006 (The Constitutional Court of the Republic of Indonesia 2006).

Leiter, Brian. "Legal Formalism and Legal Realism: What Is the Issue?" University of Chicago Public Law E Legal Theory Working Paper 320 (2010). http://chicagounbound.uchicago.edu/cgi/viewcontent. cgi?article=1178\&context=public_law_and_legal_theory.

Pacelle Jr, Richard, Brett Curry, and Marshall. Decision Making by the Modern Supreme Court. Cambridge: Cambridge University Press, 2011.

Siahaan, Maruarar. Undang-Undang Dasar 1945: Konstitusi Yang Hidup. Jakarta: Sekretariat Jenderal dan Kepaniteraan MKRI, 2008.

The 1945 Constitution of the Republic of Indonesia (1945). 
The Constitutional Court of the Republic of Indonesia. "Catatan Hakim Konstitusi Soedarsono: Putusan Mahkamah Konstitusi Tanpa Mufakat Bulat.” Sekretariat Jenderal dan Kepaniteraan MKRI, 2008.

___. "Ikhtisar Putusan Mahkamah Konstitusi 2003-2008." Sekretariat Jenderal dan Kepaniteraan MKRI, 2008.

___ . "Konstitusi Sebagai Rumah Bangsa: Pemikiran Hukum Dr. Harjono, S.H., M.C.L. Wakil Ketua MK.” Sekretariat Jenderal dan Kepaniteraan MKRI, 2008. "Menegakkan Tiang Konstitusi: Memoir Lima Tahun Kepemimpinan Prof. Dr. Jimly Asshiddiqie, S.H.,Di Mahkamah Konstitusi." Sekretariat Jenderal dan Kepaniteraan MKRI, 2008.

___ . "Sang Penggembala: Perjalanan Hidup Dan Pemikiran Hukum A. Mukthie Fadjar (Hakim Konstitusi Periode 2003-2008),." Sekretariat Jenderal dan Kepaniteraan MKRI, 2008.

Tushnet, Mark. "New Forms of Judicial Review and the Persistence of Rights-and Democracy-Based Worries." Wake Forest Law Review 38 (2003).

Tushnet, Mark, and Rosalind Dixon. "Weak Form Review and Its Constitutional Relatives: An Asian Perspective in Rosalind Dixon and Tim Ginsburg." In Comparative Constitutional Law in Asia. Massachusetts: Edward Elgar Publishing, 2014.

Young, Katharine. "A Typology of Economic and Social Rights Adjudication: Exploring the Catalytic Function of Judicial Review." International Journal of Constitutional Law 8, no. 3 (2010): 385-420.

- - Constituting Economic and Social Rights. Oxford University Press: Oxford University Press, 2012. 